\title{
Crossing the border. Migration flows in the Mediterranean sea ${ }^{1}$
}

\author{
Marta Vignola \\ Università del Salento - EMUI
}

http://dx.doi.org/10.5209/rev_NOMA.2013.v39.n3.48323

\begin{abstract}
- Madam, we want to know if you are fit enough to enter the new world. - Who do you think you are, God, to decide who's good or not good to enter the new world? Nuovo Mondo by Emanuele Crialese, 2006
\end{abstract}

\begin{abstract}
Alessandro Dal Lago wrote in 1999 that equality of all human beings and their right to freely move around the world are obvious principles although lack a clear legal drafting. Nevertheless "human kind is divided into majorities of national citizens holding rights and with formal guarantees, and minorities of illegitimate foreigners (neither citizens nor fellow country men and women) who are legally and factually denied these guarantees» (Dal Lago, 1999:9). Today policies and representations of migrants in Italy and Europe confirm the increasing disintegration of values such as humanity and rationality faced with a renewed (not only cultural) racism. The current economic crisis and the return of nationalism in the wake of the ongoing globalization are the framework within which a zero tolerance policy is reiterated towards these masses. In the age of global mobility the discussion is being reopened, as if we were suddenly back in the darkest Middle Ages, on people's freedom to move in a shared space searching for their own life and future plans. The acknowledgement of a ius migrandi and the related debate, together with a new possible epistemology of frontiers (Rodríguez Ortiz 2011, Trigo 1997), continue to be themes for reflection no longer and not only for social science.
\end{abstract}

The following writing is the result of a project carried out by a group of researchers of the University of Salento called "H.O.S.T. - Hospitality, Otherness, Society and Theatre" that tried to describe migratory experiences overcoming barriers between different subjects and interacting with the artistic environment linked to the Astragali city theatre in Lecce.

Our aim was to consider the migration theme while keeping two perspectives intertwined: the sociological research and the artistic research and practice. We chose to follow a path, which is both symbolic and physical, along a number of key places, the stops of contemporary migration in Europe: Salento, Paris, Cyprus, Cadiz, Nicosia, Patras and Zakynthos. Indeed these embody today the so-called Mediterranean model of migrations (Perrone 2007). A model that has slowly though constantly developed during the second half of the 1970s when,

\footnotetext{
${ }^{1}$ For this writing I owe particular thanks to Andrea Rea, Director of the Groupe de recherché sur les Relations Ethniques, les Migrations et l'Egalitè (GERME) of the Sociology Institute of the Université Libre de Bruxelles where I was visiting researcher during the months of May and June 2013. For other discussions conducted, in different moments on the theme studied in this research I would like to thank Mariano Longo, Paolo Jedlowski, Matteo Pagliara, Corrado Punzi, Lorenzo D'Uva and Susi Cecere, Eleonora Nestola and Antonio Guida.
} 
following the oil shock, the decennial workforce demand from North-central European countries was interrupted. This caused migratory flows to shift to countries of the northern Mediterranean shore which, at that time, lacked a coherent system of rules on immigration.

In these border and crossing places sociological research and artistic practice substantiated each other by giving a voice to the experiences of migrants, artists and researchers. The stop in Salento was for us researchers particularly meaningful because we questioned again our migrant' status from our very birth in a borderland. Moreover, by choosing for the research in Salento a particularly complex category of migrants, such as that of asylum seekers, we tried to share for a number of weeks moments of everyday life with the people we decided to interview in the facilities where they were lodging through the SPRAR project (Protection system for asylum seekers and refugees). Sharing everyday life experiences helped us reconstruct a migration story which is partly far from life stories that asylum seekers are often forced to tell in the order required by the legal and administrative procedures needed for the recognition of refugee status.

The following is a short theoretical reflection on migrations and on the concept of border that has flanked us since the beginning of this project.

\subsection{Borders in the age of global mobility}

Marking borders is a way of exercising control over population, a technology of power based today on a renewed governmentality, in a foucaultian sense, able to modify the balances between security and freedom, by enlarging the surveillance space in and outside States starting from their boundaries and their underlying power relationships. The favourite target of this modern governmentality on the border are immigrants. A new elimination experiment of the human surplus to be added to the criminalization of those individuals who are traditionally considered at the margins of society because they are marginal: drug addicts, poor people and deviants. The war to different people, to strangers and foreigners is now a total social fact because it penetrates into the current neoliberal societies through communication practices founded on the power asymmetry between individuals enjoying rights and individuals being denied rights, between people and non-people (cf. Palidda 2009 and Dal Lago 1999). Security narratives that build new threats and dangers linked to the indiscriminate access of external enemies who would hit the sovereignty and security of national communities. The migration flows that have involved most European countries over the last few years have caused the rise of a form of "apartheid" for immigrants from "non-member countries". A dangerous people in conflict with the need to patrol state-owned facilities, that are put under surveillance, deprived of basic human rights and forced to permanently live on the border:

«neither absolutely inside nor totally outside, [...] It would be naïve to think that the development of such an institutional racism in Europe has no relation to the ongoing process of globalization. [...] I think it is more accurate to see a double effect of projection of the new global hierarchy of powers, opportunities for development, and 
personal rights and of defensive reaction to globalization. This differential inclusion of European apartheid in the process of globalization no doubt explains why, more and more, the traditional figure of the external enemy is being replaced by that of the internal enemy. It also refers to an economy of global violence that, for a decade or two now, has been transformed to the point that there are no longer any regions that can be considered refuges» (Balibar, 2004:172)

The migration management, at a European level and beyond, has increasingly turned into a security-sovereignty issue supported by new transnational actors acting as "security bureaucrats beyond the state"(Bigo 2000) who, through the use of the institutional knowledge and disciplinary technologies have not only redefined new risks, but also transferred a strengthened permanent control from borders to city centres. Over the last few years a new European regime of border control has been created which is aimed not at strengthening a fortress wall but rather, according to Mezzadra,

«at managing a process of differential inclusion of immigrants. [...] Even though the control policies of the European external borders have rhetorically tried to stop refugees' and migrants' movements they haven't had the effect of sealing off borders. No fortress wall has been built but rather a "barrage" system, a "filtering" mechanism, a system to control mobility». (Mezzadra, 2007: 31-41)

A number of authors state that the current de-bordering process would make global borders fluid and porous thus enabling an increasingly freer circulation of people and goods. Actually the processes we are witnessing are just an economic liberalization of borders and their security rearrangement: a border regime, according to Sassen, aimed at the management of differential mobility processes regarding different categories of people and goods (Sassen 2009, Sassen 2008). A police story and practice that legitimates states to protect citizens through the systematic use of violence on frontiers which are now becoming permanent territories of exception. A filtering system more than a blockade against undesirable minorities, a management of the mobility of migratory flows which aims at the quick border-crossing of "good faith travellers" and at discouraging the access of those who intend to elude immigration laws. This two-fold objective perfectly embodies the paradox of international policy on migration issues. A border reconfiguration policy resulting in both security and insecurity. (Rea, Jacobs, 2011) This policy, through visible means such as border check operations, administrative detention centres, and invisibles means such as administrative (and often arbitrary) procedures established to filter categories of immigrants and to gather information on them, puts under surveillance all kinds of human mobility presenting each immigrant with a "migratory risk" (Rea 2013, in press, Processes of bordering in the age of mobility). The result of these coercive and preventive measures is the creation of categories of "desirable" and "undesirable" people, even before they arrive at the frontiers. (Bigo 2010)

\subsection{Borders, distances, race mixing}

Are borders only something marking separation, inclusion through exclusion, or better, a space for hybridization, race mixing and an opportunity to approach the Other? Considering borders as a wider category, without excluding his violent 
character, led us to add auto-biographical traces starting from our physical and geographical position on the border. This writing was drawn up on the outskirts of Europe: southern Italy, Salento. However our work was started in Brussels, the capital of Europe, where we moved for bibliographical reasons, and finished in Salento. Thus, it is a reflection that started on the border, at the margin, moved to the centre during its theoretical working out and then returned to the border. A reflection that, in a regime of geographical and physical immobility, would not contain such remarks. Beginning a journey while carrying out a study on migrations induced in us a feeling of disorientation in both a physical and a symbolic sense, an openness to multiple experiences that took us a little away from the main subject and brought us closer to feeling as though we were strangers in a country with different roads, language and nuances. A journey which forcefully changed both our temporal and our spatial location. A different temporality at a different speed: the meridian rhythm of the start became the syncopated rhythm of the North, our destination. This shared feeling of initial disorientation was the start of one attempt to imagine the conditions of those who travel for reasons other than ours. It is indeed true that «[...] in the current world situation, according to social science, everybody has some immigrant's features. We are living on multiple borders. There are many kinds of migrants and many ways to be a migrant.» (Floriani 2004, from Jedlowski:6).

Writing while travelling and feeling the sense of tiredness and estrangement, though in a marginal and temporary way, the nostalgic loneliness felt also by those "vagabonds"/migrants, as defined by Bauman, at their arrival in a foreign land. It was a way to reconsider a number of categories taken for granted from a different point of observation. (Baumann 1999) Also because those travellers who, according to Matera,

«feel the distinctive "disorientation", do not recognize usual places and forms, must twist their conceptual tools to understand and their linguistic tools to describe.

The travel report is based on the ethnic monograph, but reflects first of all the reawakening of senses now filled with the perception of the otherness, which is then used to construct a thinking and writing system aimed at interpreting it». (Matera, 1986: 83)

Such a thinking system which develops through the acknowledgement of one's new placing is able to face any movement or change, tends to shift any intellectual sedimentation from the vision of the elsewhere and builds new speech spaces and new representation. Garofalo observes that studying migrations is a «journey without any definitive destination: when the journey starts we must be ready to question our safe categories and concepts from both the point of view of personal perception and a theoretical analytical point of view». (Garofalo, 2012: 23)

Our vision does not pretend to be right, but while moving from one place to another is at least privileged to be at the margins and in the centre at the same time and to avoid a non-vision which we would see if we were still.

Rethinking ourselves while we were moving has made the method more difficult but has certainly kept both the interpretative fluency and openness which are fundamental to carry out an analysis of migratory flows. Therefore we have 
tried to gain access to the dialectics of living on borders where migrants are the exemplary figures, and the border is considered as a place where differences touch each other and test their limitedness through each other. (Mezzadra 2011) We have considered ourselves closely linked to the border idea, starting from our birth in a borderland which means, as defined by Carmelo Bene, to address to "the real/imaginary" (Carmelo Bene 1983).

\subsection{A liquid border}

Mediterranean outskirt Salento is a borderland with people forced to stay on the border. Here the border is the Mediterranean Sea which is not only the starting point but also the landing point. As suggests Braudel (Braudel 2003), the Mediterranean is understood as space/movement where nothing is immobile but everything is transformed, contaminated, hybridized leaving visible and invisible traces on the surface and on the bottom:

«The Mediterranean is a multitude of maritime and land routes, linked amongst themselves, hence cities, from the most humble to medium and large, all holding each other by the hand. Roads, more roads becoming a system of circulation. Through this system we can fully understand the Mediterranean Sea that can be defined as space-movement in its broadest sense. The landscape and the sea (the basis of its everyday life) are added to the gifts of movement. The faster the movement the larger the amount of gifts which take shape in visible consequences» (Braudel 1992:51)

The Mediterranean Sea is the limes which urges us to use a kind of interaction that is able to catch the sense of differences, the heterogeneity of parts related to each other, a kind of interaction through differentiation experienced especially by younger generations who are more permeable to cultural contaminations (Cusumano 2010).

Speaking, writing, telling, listening to migrations meant speaking, writing, telling and listening to ourselves and the Mediterranean. Cassano wrote in his Pensiero meridiano : «today Mediterranean means to put the border in the centre, the line of contact and division between people and civilizations [...] this sea is at the same time internal and external, inhabited and crossed, this seaborder interrupts the rule of identity and aims at forcefully hosting division.» (Cassano, 2007: 23) A division which, in this place, is the awareness of being race mixed from our birth. In Salento, on the days when the tramontana blows we can see the Albanian mountains, whereas Radio Tirana frequencies break into our car along the Adriatic coastline and we receive on our cell phone welcome messages from Greece. It is also a linguistic Babel, when we hear the sweetness and musicality of the griko of our parents in some villages of the "Grecia Salentina"2. Our somatic features are often conflicting with each other and the same is true for landscapes: blond hair, light eyes, very dark skin owing to Turkish, Norman, Spanish and Greek dominations. Living in a land like Salento means living in a land antithetical to any pureness and fundamentalism, where a monolithic and integral "we" does not exist because our "we" is filled with "others" (Cassano 2007). This does not mean making an apology of our territory but rather telling an experience of marginality or better telling from an

\footnotetext{
${ }^{2}$ The Grecia Salentina is an ellenophone region of Salento located in the province of Lecce where a neo-Greek dialect is spoken known as grecanico and Griko
} 
experience of marginality. Marginality is now chosen as a place of residence which becomes a space of radical openness and opportunities for the production of a counter hegemonic discourse [...] present not only in words but also in the ways of living and being" (Bell Hooks, 1998: 68-72).

A borderland with people forced to stay on the border is:

«a vague and undetermined place created by the emotional residue of an unnatural boundary. It is in constant state of transition, as stated Mexican sociologist Gloria Anzaldua, the people living on the border are los atraversados: the squint-eyed, the perverse, the queer, the troublesome, the mongrel, the mulatto, the half-breed, the half dead; in short, those who "cross over, pass over, or go through the confines of the 'normal'» (Anzaldua, 2006: 29)

Salento is a borderland filled with passageways, contradictions and conflicts but is also a land of crossings, of meetings just like any other borderland. Living on the border means giving a new meaning to one's identity, and our identity was crossed and fecundated by migrants. Furthermore ours is a border placed in the South where, as happens in other southern parts of the world, the resulting thought is a meridian thought in the sense suggested by Cassano, that is a thought which one can feel inside: "where the sea begins, the shore breaks the earth's fundamentalism (first of all that of economy and development), when it is clear that borders are not places where the world ends, but rather where different people meet and a new challenge for the relationship with the other becomes true and difficult»(Cassano, 2007: 7). Then migrations have been a pretext to tell ourselves, to listen to ourselves again: a listening education to find out that we are migrants in migrants' stories and "I" becomes "You", because no identity exists without otherness in and out of ourselves. Our aim was not to tell and build migratory identities, but rather to give a new voice to migrants. We tried to stay silent in order to listen to their voice, which made a "surprising representation of ourselves" (Cassano, 2007: 34). Considering migrants without studying, judging and analysing through external categories has meant (to us) returning them the dignity of autonomously thinking individuals, thus interrupting a long tradition where they are thought by others. As a consequence the forbidden speech of the infamous people has been also our speech, and their story has become a narrative practice of shared resistance. Nevertheless we could have probably produced further stereotypes and clichés while translating and choosing one interpretation of those stories and voices; anyway we could not avoid to use an approach which is autobiographic, narrative and subjective of migrations. As the Cameroonian writer and anthropologist Geneviève Makaping states:

«there is the need to make my voice heard. I'm not just telling my pain, I want you to know my story, a story that must not be told by a different, or even worse, my colonizer [...] l'm not to be praised by those who think to tell my story better than I could do [...] I want to be the one who says my name» (Makaping, 2001:53)

This quote comes from a book whose title contains a question posing us a doubt (and also a challenge) that was the main subject of our work: "what if the others were you?" Yes, if we were the others ? We have tried to be constantly moving in order to change our point of observation, both internally and externally, while trying to listen to the countless voices of the Mediterranean. The Mediterranean Sea is not a borderless ocean but rather a sea between 
lands; unlike other seas it has the problem of the relationship between multiple identities, of the difficulties of living necessarily together. The Mediterranean is a border sea, his position could turn it into a privileged place for intercultural dialogue. Remaining on the Mediterranean, at the margins, has brought back the problem of the relationship between different identities and cultures that had to live together in such a difficult but necessary way. This is not a question of not resisting the romantic temptation to imagine a mythic place - a utopian Mediterranean landscape. Instead, this is a question of thematizing a place, real and symbolic at the same time, which can be an alternative to the oceanic drifts of globalization (Cassano, Zolo, 2008), which is able to grasp and question emerging themes such as immigration policies, the relationship between Islam and modernity, the Mediterranean roots of such Europe that has difficulties in finding its own legitimization, autonomy and identity.

\section{Narration beyond borders}

Our attention is to be focussed on the immigration actors starting from an autobiographical approach to a sociological classic work: The Polish peasant in Europe and America by Thomas and Znaniecki. Moreover, the works of the young Weber on the conditions of agricultural workers in the Eastern Prussian provinces present us with a detailed study of the migrations of German peasants ${ }^{3}$. What strikes in Weber's work is the consideration of migrants' subjective reasons, revealing aspects studied by social science only in the 1920s owing to the analyses published by the researchers of the Chicago School. While carrying out an in-depth study on the migration dynamics developing at that time in the Prussian countryside, Weber highlighted the subjective point of view of the young German migrants by identifying their will to escape from the authoritarian and paternalistic oppression of landowners as the main reason for them to abandon their land and seek freedom.

In his work Diritto di fuga Mezzadra reminds us that we owe to Weber the intuition of the «origin of migration as an individual refusal, a claim of a right to secession and escape from the patriarchal organization in force in the Eastern Prussian territories, which becomes a social process to the same extent that it appears standardized» (Mezzadra, 2006:48)

Furthermore, Mezzadra underlines the need to highlight the subjective features of migrations that question «the migrant figure of a weak subject, hollowed by hunger and misery and needing care and help which have been widely diffused, particularly in Italy, over the last few years». (Mezzadra, 2006: 11)

Discussing the subjective character of migrations and also their natural unpredictability or turbulence (Papastergiadis, 2000), means not considering the prevailing interpretation of migrations as a systemic event exclusively linked to the objective causes of migrations. This does not mean to remove such causes, but rather to try and return a personal history to subjects too often considered

\footnotetext{
3 In his book The right to escape. Migrations, Citizenship, Globalization, Sandro Mezzadra starts from an analysis of the studies conducted by Max Weber during the 1890s on the conditions of agricultural workers in the provinces of Eastern Prussia on behalf of the Verein für Sozialpolitik. Sandro Mezzadra The right to escape. Migrations, Citizenship, Globalization, Verona, Ombre Corte 2006, pages 46-48
} 
"without history" (Mezzadra, 2006: 52). The "hydraulic" macro models, by privileging the expulsion reasons in the country of departure and the causes for attraction in the countries of arrival linked to an economic determinism, are useful to explain the general features of the migration event and some of the objective reasons, but are unable to read the deep subjective nature of a migrant, who is not only a pawn, workforce in the hands of a system - a world subject to market rules. Choosing the subjective migrant option also means acknowledging and legitimizing the exercise of the right to escape describe by Mezzadra, which reveals:

«the irreducible singularity of a migrant able to make subjective choices, highlighting the exemplarity of the migratory experience as a limit of the modern political experience. This limit forces us to re-think the overall reference framework so as to strengthen the ongoing reflections for a political analysis of contemporary migrations.» (Mezzadra, 2006: 52 and following)

The material used to write this research project is only made up of the stories that migrants tell. They tell us their stories, but we are neither deaf nor aphonic and let these stories involve ourselves by breaking the limit. And these stories become also ours. We chose the biographical interviews because we thought that their use could open an alternative path to knowledge and sociological research able to interrupt a prevailing belief on migrations. The use of an autobiographical method and its underlying retrospective reflection are able to activate the discovery of new, unexpected identities, communities and links. As a matter of fact, the constituent narration of biographical interviews is a cognitive practice for both the interviewed and the interviewer because, as suggests Jedlowski, there are always two people narrating and sharing a story, one narrator and one listener (Jedlowski 2009). It is about a reflective practice where everybody recognizes themselves, in themselves or in the others, since the description of the other by oneself is always a definition of the self. This generates in the autobiographical narration an attempt to recognise and redefine the self as a dynamic instance that can give birth to a manifold, wandering, nomad identity lacking stability and able to present various dimensions (Di Stefano, educatt.unicatt.it).

Indeed narration triggers off a new sense construction and re-construction process that is not confined to one's biography but can be generalized because the autobiographical narration is composed of memory production, identity, individual and collective belonging. The issue of the generalizability of life stories seems to be solved through the simple remark expressed by D. Bertaux and quoted by Di Stefano:

«multiplying the stories of people in situations comparable to each other it is possible, on the one hand, to grasp all subjective features expressed whereas, on the other hand, to draw a more far-reaching sociological picture. [...] Real history does not coincide with the story: the history of an individual has got a reality which precedes the story itself; just like diachrony, the temporal succession of events, does not coincide with chronology, their dating in terms of years. However, the objective is to reconstruct the diachronic dimension of events and put it in the collective historical time which embodies the social change, the life style of different generations and is distinguished from the subjectivity of biographical time». (Di Stefano, educatt.unicatt.it: 45)

Through the use of life stories it is possible to understand the wider historical processes crossing the everyday life of single biographies: 
«[...] it is an attempt to connect what is macroscopic to the microscopic world where everyone is placed. This means recognising everyone's role, main or secondary, in promoting, hindering or accompanying great social changes giving them a sense, by adapting themselves and adapting them to their own context» (Jedlowski 2009: 49-50).

The story, the autobiography can have in this sense many individual and social meanings; it can become a means for memory transmission and re-definition of personal and collective identity. "In a certain sense an individual», as Pecchinenda suggests, «has got no story, but is the story» (Pecchinenda, 1999: 176). Stories are not only produced through the language that can lead to different versions, but narration becomes soon fundamental for social interactions:

«We constantly construct and reconstruct ourselves to meet the needs of the situations we encounter, with the guidance of our memories of the past and our hopes and fears for the future. [...] There is now evidence that if we lacked the capacity to make stories about ourselves, there would no such thing as selfhood. [...] The construction of selfhood, it seems, cannot proceed without a capacity to narrate. Once we are equipped with that capacity, we can produce a selfhood that joins us with others, that permits us to hark back selectively to our past, while shaping ourselves for the possibilities of an imagined future». (Bruner, 2002:86-87)

For the collection of life stories we deliberately tried to tell and listen to a particularly delicate category of migrants: asylum seekers. I will not discuss the reasons for such a choice since for us it was a "natural" fact. A natural sociological and human curiosity to understand women and men who arrive at our border neither for economic reasons nor for an improvement of their life standards, but rather to protect life itself. People who, in the countries of arrival, are often subject to further humiliations imposed by a widespread tragic common sense according to which asylum seekers are nothing but beggars resorting to expedients to obtain the access to "hosting" territories, also by testifying violence and persecutions perpetrated against them (but never happened), or dead bodies that, according to the police, have never existed (Vassallo 2010).

So far very few, at least in our region, has been told on this category. Still less has their voice been listened to. Moreover, it is a category we chose because it is a challenge for narration. Their and our narration.

It's been a challenge for us because the stories of asylum seekers are often reticent, sometimes because telling pain is so terrible that one remains dumb and inaudible at the same time; "sometimes stories are inconsistent and actually false owing to migrants' desire to adapt their stories to the provisions ruling the right to asylum» (Jedlowski 2012). Indeed, on several occasions we have noticed in migrants' voices not the expression of their subjectivity but rather the construction of a speech order that is abstract and forced by our bureaucratic procedures for the achievement of the refugee status. A series of pretenses followed most times by:

«false statements on their arrival in the attempt to hide their identity or to highlight the ethnical or identity-making features considered reliable in view of the right to asylum, [...] and a series of progressive shifts of migrants to forms of alteration of the self which sometimes are irreversible and cause interior fractures as well as renewed grounds for expulsion». (Triulzi, 2007: 10) 
We chose to hear their stories because it seems that the right to asylum has become a matter for abstract and invisible officers of nation and international institutions who evaluate the applications for asylum on the basis of a weak legal regime after summing subjective opinions that often reveal a discretional character resulting from «a technocratic power-wielders that are subject to political and ideological bias» (Valluy, 2009: 45).

The story use has assumed an extraordinary value of resistance and life stories have become counter-narratives, antenarratives:

«or better narrative fragments without any (current and future) consistency and organization of true stories, but with the expression of the possibility to tell in ways other than the current. [...] they continue to be potential repertoires of alternative visions of facts that, in case of conflicts, can turn into embryos of stark counter-narratives, resources for the construction of alternative communities» (Jedlowski, 2009: 36).

Alternative communities resulting from "narrative communities" as defined by Jedlowski, or better "a group of individuals who accept to exchange the roles of narrators and listeners. [...] a community of people that share their stories» (ibidem: 32-38).

A narrative community is maybe what we have tried to construct by opening a space, a friendly environment where every story, every word has had an equal right to exist and resist, without interdict, without any kind of exclusion imposed by the prevailing rhetoric. We believe that only through the attempt to return the right of speech to those deprived so far can new links be generated and thus new forms of community able to find a sense of future together.

\section{$\underline{\text { Post-scriptum }}$}

At the conclusion of our study on migrations we have realized to what extent this macro theme can question the very foundations of democracy, selfhood and citizenship. Migrants cause us to radically re-think these themes by placing them back in the public field in a new form, proposing new challenges, new pictures, new languages and new practices. Their mobility itself is a strategic resource to start change processes not only in the countries of arrival but also in the places of origins ${ }^{4}$.

Far from being a category of revolutionists, migrants can trigger off processes of subjectivity construction introducing new legal, political and social issues. They can be political factors of deep transformations starting from the urgent need to rebuild the relationship between rights and citizenship at the basis of the balance between universalism and particularism in citizenship issues; a balance that has to secure for migrants «those political, civil and social rights that enable us to participate in all aspects of common life as full members of society and that would promote their sense of belonging and help soften possible conflicts» (Mezzadra, 2006: 87-88). Therefore, migratory experiences, while being an opportunity to enlarge the democratic and epistemological standard of cultural,

\footnotetext{
${ }^{4}$ Consider the recent feminization of flows and the subjective reasons which cause women to migrate, inevitably modifying the dynamics of private and familiar life as well as the public and political situations of the countries of origin and arrival.
} 
racial and distributive pluralisation of democracy, can make room for and guarantee the plausibility of anti-hegemonic democratic practices and concepts by outlining new emancipatory horizons.

Our proposal is to make a reflection that can touch the constituent values of Europe by urging its countries to imagine a form of citizenship that, though "imperfect" (Balibar 2012 and 2004), can secure for every migrant not only a right to migrate - ius migrandi - (Vitale 2004), which would be an extraordinary conquest and a revolutionary outlook, but first of all the right to have rights; a citizenship which has to increasingly include those individuals who were at first excluded and, at the same time, has to be open to wider reasons for the foundations, the acknowledgement and the protection of human rights. Democratizing democracy, also by welcoming possible social rivalries resulting from new subjective instances of migrants, enables us to constantly generate inclusive and expansive dynamics for a new map-making of fundamental rights: «these new, unpredictable and uncontrollable actors of the post-revolutionary legal system [...] who are potentially subversive not only against power but also against any consolidated and out-of-date expression it assumes» (Ferrarese, 2002: 122).

References

Anzaldúa G., (2006), La frontera/Borderlands. The New Mestiza, Aunt Lute Books, San Francisco

Balibar E., (2004), Noi cittadini d'Europa? Le frontiere, lo Stato, il Popolo, Manifestolibri, Roma

(2012), Cittadinanza, Bollati Boringhieri, Torino

Bauman Z., (1999), Dentro la globalizzazione. Le conseguenze sulle persone. Laterza, Bari.

Bene C., (1983), Sono apparso alla Madonna: vie d'(h)eros(es), Longanesi, Milano

bell hooks, (1998), Elogio del margine. Razza, sesso e mercato culturale, Feltrinelli, Milano

Bertaux D., (1999) Racconti di vita. La prospettiva etnosociologica, Franco Angeli, Milano

Bigo D, J.Jeandesboz, F. Ragazzi, P. Bonditti,"Borders and security: the different logics of surveillance in Europe" in Bonjour, Saskia, A. Rea and D. Jacobs, The Others in Europe, 2011, Brussels, Editions de l'Université de Bruxelles.

2000, Sicurezza e immigrazione. Il governo della paura. I confini della globalizzazione. Lavoro, Culture, Cittadinanza, a cura di, S. Mezzadra and A. Petrillo. Roma, Transizioni.

2010, "Freedom and Speed in Enlarged Borderzones". In V. Squire, The Contested Politics of Mobility. Borderzones and Irregularity: London, Routledge; 
Braudel F. (2003), Il Mediterraneo - Lo spazio, la storia, gli uomini, le tradizioni, Bompiani, Milano

Bruner J., (2002), La fabbrica delle storie. Diritto, letteratura, vita, Laterza, Roma - Bari

Campesi G., (2012), Migrazioni, Sicurezza, Confini nella teoria sociale contemporanea, n.2, Carocci, Roma

Cassano F., (2007), Il pensiero meridiano, Laterza, Bari-Roma

(2008) Zolo D. , a cura di, L'alternativa mediterranea, Feltrinelli, Milano

Cusumano A., (2010), a cura di, Palmisano E., Argonauti, Mare e migranti, Officine Grafiche Riunite, Palermo

Dal Lago A., (1999), Non Persone. L'esclusione dei migranti in una società globale, Feltrinelli, Milano

Distefano S., II tempo del racconto, La narrazione come percorso di conoscenza sociologica, educatt.unicatt.it

Ferrarese M. R., (2002), Il diritto al presente, globalizzazione e tempo delle istituzioni, II Mulino Bologna

Floriani S., (2004), Identità di frontiera. Migrazione, biografie, vita quotidiana, Soveria Mannelli, Rubbettino.

Garofalo S., (2012), Messaggi nella bottiglia. Percorsi di donne migranti nel Mediterraneo, Aracne, Roma

Jedlowski P., (2009) Il racconto come dimora. Heimat e le memorie d'Europa, Bollati Boringhieri, Torino

Maestri nel mondo - XV convegno dei Centri Interculturali Napoli 26/27 ottobre 2012, Culture e narrazioni di sé.

Longo, M., (2001), Strategie dell'esclusione e riconoscimento dell'altro, Manni, Lecce

(2012) Il sociologo e i racconti, Carocci, Roma

Matera, V., (1996), Raccontare gli altri, Argo, Lecce

Makaping G., (2001), Traiettorie di sguardi. E se gli altri foste voi?, Rubbettino, Soveria Mannelli

Mezzadra S., (2007) Confini, migrazioni, cittadinanza, Papers. Revista de Sociologia, n. 85, Barcellona

- (2006) Diritto di fuga. Migrazioni, cittadinanza, globalizzazione, Ombre corte, Verona

Rodríguez Ortiz R.,(2011), Epistemología de la frontera: los límites del otro, Ideação, Revista do centro de edução e letras da unioneste - Campus de Foz do Iguaçu, v. 13 pp.11-28, 2011

Palidda, S.,(2009), a cura di, Razzismo democratico. La persecuzione degli stranieri in Europa, Xbook, Milano

Papastergiadis N., (2000) The Turbolence of Migration. Globalization, Deterritorialization und Hybridity, Cambridge, Polity Press 
Pecchinenda G., (1999) Dell'identità, Ipermedium libri, Napoli

Rea A., Triepier M., (2009), Sociología de la Inmigracíon, Hacer Editorial, Barcelona Mobility

Rea A. (2013), in corso di stampa, Processes of bordering in the Age of

Tusa S., (2010), Dal passato al presente in un mare di migranti, in Argonauti. Mare e migranti, a cura di, E. Palmisano, Officine Grafiche Riunite, Palermo

Trigo A., (1997), Fronteras de las epistemología, epistemologías de la frontera, Revista Papeles de Montevideo, Literatura y cultura, La crítica literaria como problema, n.1 junio, pp.71-89.

Triulzi A. Carsetti M., (2007) Ascoltare voci migranti: riflessioni intorno a progetto sui richiedenti asilo del Corno d'Africa, in Numero speciale "Il ritorno della memoria coloniale", a cura di A. Triulzi e R. lyob, Afriche \& Orienti, 1.

Valluy, J., (2009), La metamorfosi dell'asilo in Europa. Dalle origini del "falso rifugiato" al suo internamento, in Razzismo democratico. La persecuzione degli stranieri in Europa, a cura di, S. Palidda, Xbook, Milano, pp.44-53

Vassallo Paleologo F., (2010) La nuova dimensione esterna delle politiche comunitarie in materia di immigrazione e asilo, in Argonauti, Mare e migranti, a cura di, E. Palmisano, Officine Grafiche Riunite, Palermo

Vitale E., (2004), Ius migrandi. Figure di erranti al di qua della cosmopoli, Bollati Boringhieri, Torino 